\title{
Identification of Gondang Batak Toba Learning Needs in Toba District
}

\author{
Rekson Benyamin Purba*, Yudi Sukmayadi \\ Universitas Pendidikan Indonesia \\ Bandung, Indonesia \\ *benyaminrekson@upi.edu,yudi.sukmayadi@upi.edu
}

\begin{abstract}
Ethnic musical instrument is one of the identities of a culture that should be preserved by various groups, including children who are still in schools. However, in reality ethnic musical instruments especially the Toba Batak gondang that are available in the schools today can be said to be inadequate both in terms of quantity and quality, thereby reducing the interest of students to study Toba Batak gondang as ethnic music. Unlike the rapid technological advances, these students pay more attention to the development of mobile phones and laptops as tools used daily because access to various needs can be found easily. To find a solution to this problem requires a theory of Need Identification and a theory of learning ethnic music instruments. So, this study used a qualitative descriptive. The data collection used interviews teachers from several schools in Toba district. Based on the interview, it was found that in the learning activities of ethnic music, it is necessary to have a learning media that contains imitations of ethnic musical instruments and is able to be an alternative in learning ethnic musical instruments with simple basic features so that they are easy to use. It is expected that with this learning media students' interest in learning ethnic musical instruments will increase so that learning objectives can be achieved.
\end{abstract}

Keywords-learning media, ethnic music instrument, identification of needs, Toba Batak Gondang

\section{INTRODUCTION}

Nowadays, ethnic musical instruments, particularly Toba Batak Gondang, are rarely found because of the decreasing number of craftsmen and users, even though ethnic musical instruments are included in one of the identities of a culture that should be preserved by all groups including the younger generation who are currently attending school. Why is that? Because it must be instilled from an early age that culture is an obligation for future generations to protect and preserve it so that it is not eroded by time. In fact, when the spirit of preserving is being encouraged, the material for ethnic musical instruments is found to be inadequate both in terms of quantity and quality. This causes the students to reduce their interest in getting to know ethnic musical instruments. On the other hand, these students are increasingly interested in technological advances that are growing rapidly. Students pay more attention to technology science now can be accessed using a network, such as mobile phones and laptops.

Departing from this fact, it takes a need identification theory and an ethnic musical instrument learning theory so that it creates a combination of learning ethnic musical instruments with technology science which can facilitate students' access to study, maintain and preserve ethnic musical instruments without reducing the aesthetics of the ethnic musical instruments. This requires a lot of contribution from students and teaching staff because this learning, even though about the integration with technology, is still in the education clump, which requires seriousness in teaching and learning activities, so that the expected collaboration of the two objects can have a positive effect on learning outcomes. in education.

Education itself has the sense of an effort to contain the system, where it is done by people who in given the responsibility to influence students to have the nature and disposition in accordance with the ideals of education [1]. Therefore, education is expected to be truly directed to make students able to achieve the process of maturity and independence.

In the discussion about combining ethnic musical instruments with technology, it is hoped that there will be a learning process. The learning process itself consists of an integrated teaching and learning process. The teaching process is the delivery of information from the knowledge facilitator to the acceptors. Apart from being a conveyor of information to students, the learning facilitator is also a regulator of the learning process and the environment in the classroom. The learning process is influenced by internal and external factors. Internal factors such as attitudes, outlook on life, feelings of pleasure and displeasure, habits and experiences in students. External factors are stimuli from outside the student through the senses they have, especially hearing and sight.

Thus the incorporation of ethnic instruments with science and technology is the right choice to use increase effective bag and learning efficiency because in need him now per flower late in the various media that creative and innovative. This is done so that the learning process does not seem less attractive, monotonous and boring so that it will hinder the transfer of knowledge. Therefore, the role of the media in the learning 
process is important because it will make the learning process more varied and less boring.

Learning media is an example of external factors that can be used to increase learning efficiency. This can be achieved because the learning media can overcome various obstacles, including: communication barriers, limited classrooms, passive attitudes of students, less uniform student observations, the nature of learning objects that are less specific so that they are not possible to learn without media, remote learning places and so on.

Advances in science and technology have influenced the use of teaching aids in schools and other educational institutions. Nowadays learning in schools has begun to be adapted to developments in information technology, resulting in changes and shifts in the educational paradigm [2]. This indicates that the use of information technology in the learning process in the classroom has become a necessity as well as a demand in this global era.

The combination of ethnic musical instruments with technological knowledge begins with an understanding of traditional music first. The traditional music of the Toba Batak tribe is called gondang, there are three meanings for the word gondang, the first is the type of Toba Batak traditional music, the second is the composition found in this type of music such as the first gondang and so on and the third is the ensemble in music Gondang Batak Toba, namely Gondang Sabangunan which is usually played outside the house or in the yard of the house, and Gondang Hasapi which is usually played inside the house.

After understanding the traditional music and musical instruments of the Toba Batak ethnic group, it is continued with the integration of technology. The science of technology that fits the problem of ethnic musical instruments is VST (Virtual Studio Technology). The use of Virtual Studio Technology (VST) in teaching and learning activities can be made in the form and learning media. Therefore, it is the writer tries to design a multimedia-based learning will assist students in learning to play music gondang Batak Toba.

The purpose of writing this article is to facilitate / help students in learning or playing gondang batak toba music by using virtual studio technology help without having the musical instrument first.

\section{LITERATURE REVIEW}

\section{A. Theoretical Review}

- Gondang Batak is a traditional musical instrument of the Batak tribe. In Batak Toba word "gondang" basically has the sense of a diverse (multifacet meaning), depending on the circumstances and the context of what and how the word is used. In contrast to the opinion of most people outside it, gondang is generally understood as the "(ensemble) of traditional music" or "gendang" of the Toba Batak people. For the
Toba Batak people, the word gondang can have the following meanings: 1) musical instruments; 2) music ensemble; 2) music reports; 3) one song composition (musical piece); 4) a ceremony; or 5) shows a certain segment of the kinship group that is manortor (social dance) in a ceremony. Gondang in the sense of a musical instrument, for example, is found in the mention of "gondang Batak;" gondang in this context implicitly implies the meaning of "musical ensemble," which is specifically to call the musical ensemble "Gondang Sabangunan," or it can also mean to mention the set of taganing musical instruments, (set-gendang pitched / tuned drums) found in the ensemble. Gondang Sabangunan. The use of the word gondang in the context of mentioning a musical ensemble can be found in the categorization of two forms of Toba Batak traditional music ensemble, namely Gondang Sabangunan (Gondang Bolon) and Gondang Hasapi; the word gondang in the context of the two words "sabangunan" and "hasapi" means "musical ensemble."

- Learning media is one example of external factors that can be used to increase learning efficiency. This can be achieved because learning media can overcome various obstacles, including: communication barriers, limited classrooms, passive student attitudes, less uniform student observations, the nature of learning objects that are less specific so that they are not possible to learn without media, remote learning places etc. Learning media occupies a strategic position in the learning process because it mediates knowledge information from teachers to students. There are many benefits provided by learning media to students. Sudjana \& Rivai argued that the benefits of media include: attracting students' attention so that it can foster learning motivation and become an alternative method of learning because students do not just get learning from one source [3]. According to Hamalik, the benefits of learning media include [4]: laying concrete foundations for thinking, enlarging students' attention, fostering regular and continuous thinking, especially

- Virtual Studio Technology is an interface for integrating audio synthesizer software and effects plugins with audio editors and hard-disk recording systems. VST and similar technologies use Digital Signal Processing to simulate traditional recording studio hardware with software. This technology was created by Steinberg. VST plugins generally come with an interface that displays controls similar to the switches and buttons 1 on the original audio equipment. VST itself is a module that requires other software that functions as a host to run it and the file type of VST is dll (dynamic link library). 


\section{MeTHODS}

This research is included in the descriptive qualitative method with initial interviews with teachers from several schools in Tobasa district. Based on the interview, it was found that in ethnic music learning activities, it is necessary to have a learning media that contains imitation of ethnic musical instruments and is able to become an alternative in learning ethnic musical instruments. This research is included in R\&D (Research and Development research).

$\mathrm{R} \& \mathrm{D}$ research is research that aims to produce products and test the effectiveness of these products. This study uses a development model that is used as the basis for developing research products. The design of this research activity only reached the feasibility test of the Gondang Batak Toba learning media with the use of VST followed by an evaluation of the final model. Thus, there are 2 steps of simplification of the research method carried out by the researcher, namely by dividing the research into 2 parts, namely: the preliminary study stage, the media development stage. Simple basic features and easy access are required so that students and teaching staff minimize difficulties in using them.

\section{RESUlTS AND DisCUSSION}

This research is included in $\mathrm{R} \& \mathrm{D}$ (Research and Development) research. Research $\mathrm{R} \& \mathrm{D}$ is a research aimed at produce the product and test the effectiveness of the product. This study uses a development model that is used as the basis for developing research products. The design of this research activity is only up to the feasibility of the Gondang Batak Toba learning media using VST.

The development model in this study uses the Allesi \& Trollip model. Stephen Allesi \& Stanley R. Trollip describes the stages in the development model which includes.

\section{A. Planning Stage (Planning)}

- Formulate goals to be achieved i.

- Prepare reference books and other learning resources that contain the Gondang Batak material

- Composing ideas as signs in the media display in the form of video content design, media content and appearance design, and production and evaluation process design.

\section{B. Stage of Media Display Framework (Design)}

- Designing scripts, scenarios, and other supporting instruments containing persons the verbal text.

- Conduct shooting (video shooting), transfer pictures (video rendering) from the camera to the computer, and the improvement of the image (video editing) on demonstration gondang Hobo with vst media.
- Creating a flowchart to operate the Macromedia Flash 8.0 program used media placement for the video and lesson content in this audio visual media.

\section{Development Stage (Development)}

- This stage is a stage incorporation of all materials were developed, including application programs that will be used is Macromedia Flash 8.0

- Export the reduced size of the video file to the audio visual media master program and then assemble it with the animation that has been prepared in the program.

- Producing video and audio, in this stage creating displays, animations, graphics, music, narration, and instruments that can support development

- Evaluating and reviewing (testing and validation)

1) Application: It becomes a learning center where students play a more active role in learning a material using the main media of computers. Analysis of the model used in multimedia-based learning applications in traditional music Gondang Batak Toba, while the application of the computerbased instruction method is as follows:

a) Material 1: Overview of the traditional gondang Batak music

b) Material 2: Overview of taganing

c) Material 3: Tone on Gondang Baak (Taganing)

- Theory

- Simulation

d) Material 5: The basic method of playing Gondang Batak ( taganing )

- Theory

- Simulation

2) Implementation: Implementation is a step used to operate the designed application. In this case, it explains how to run the application. Application processing program is a processing unit consisting of procedures and data implementation. The computer as a means of processing the program must provide supporting facilities for later processing. Proportionally must fulfill access, namely:

a) Hardware: The hardware referred to here is a set of computers, monitor speakers and keyboard controllers.

b) Software: The software used is the DAW and Vst Gondang Batak software. The display view show in figure 1. 


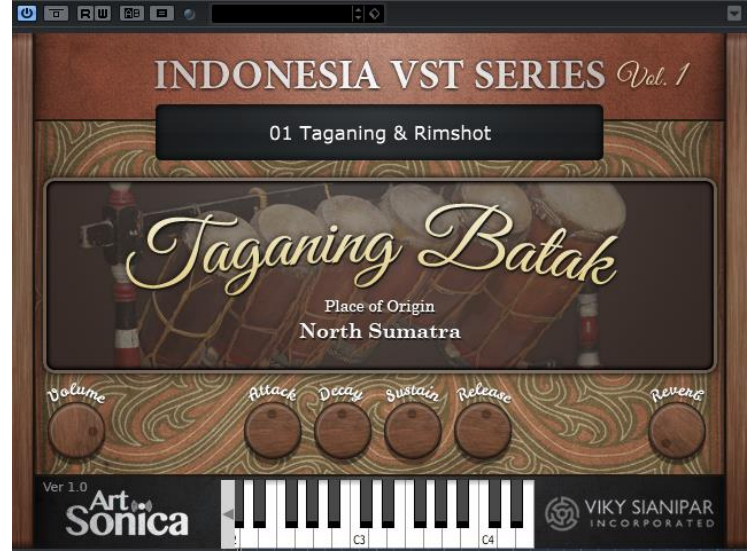

Fig. 1. Display view.

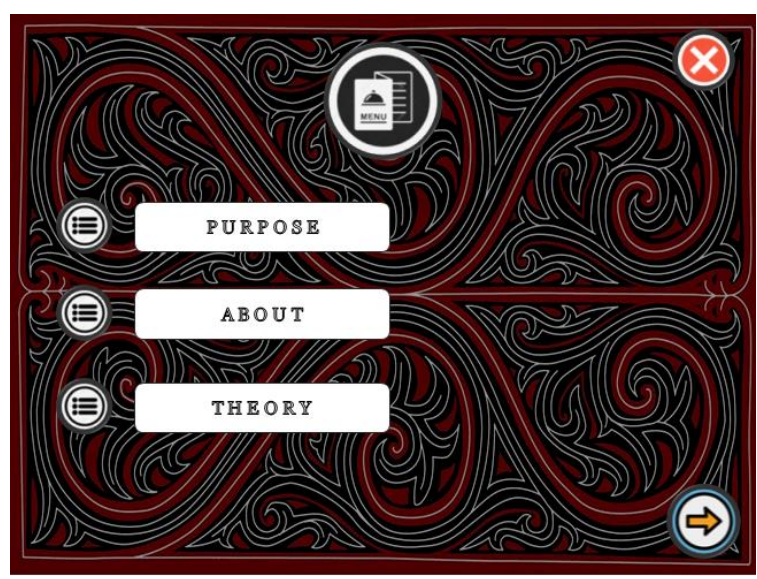

Fig. 2. Main course.

The figure 2 is the main menu which contains learning objectives, a brief introduction to the gondang batak, then the material to be discussed.

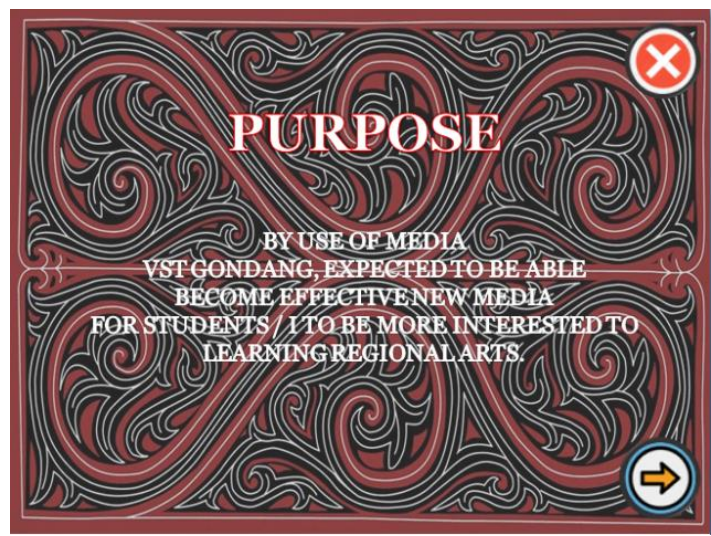

Fig. 3. Purpose view.

After clicking the Destination button on the menu, the contents of the destination in this medium will appear. The purpose view show in figure 3 .

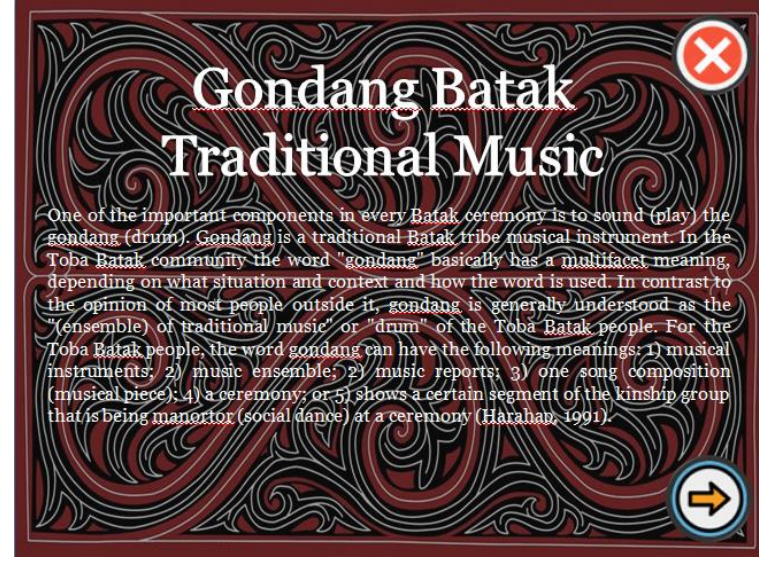

Fig. 4. About view.

Clicking the About button on the menu will display a brief explanation of the traditional music of Gondang Toba. The about view show in figure 4 .

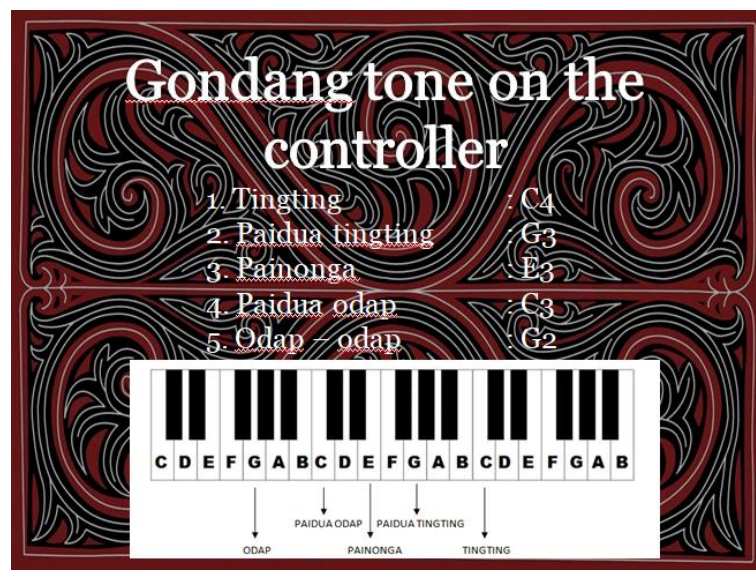

Fig. 5. Material display (Tone on controller).

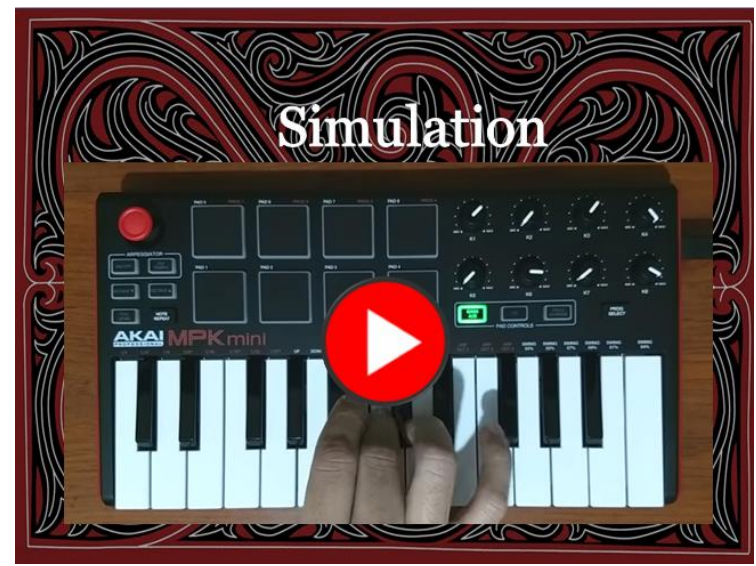

Fig. 6. Simulation 


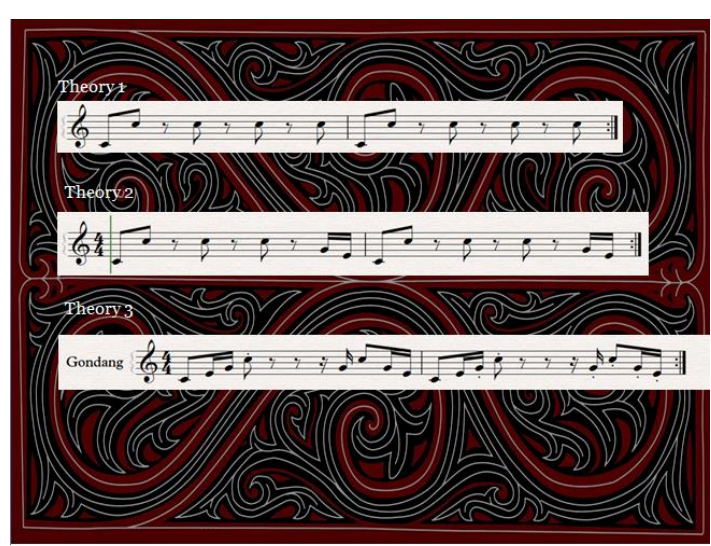

Fig. 7. Material display (Music theory).

In this section of the material, the material display (Tone on controller) see in figure 5, an explanation is given on how to play Vst Gondang Batak with a simulation video, The Simulation show in figure 6 . This material contains the basic patterns of playing gondang and their development. The Material display (Music theory) show in figure 7.

\section{CONCLUSION}

The combination of ethnic musical instruments with technology science in the field of education which is summarized in the VST nature is expected to be able to increase students' interest in learning ethnic musical instruments so that learning objectives can be achieved. Learning media can be a vehicle for channeling messages and learning information. Learning media that are well designed will really help students digest and understand the subject matter. The function of the media in learning activities is not just a teaching aid for the teacher but as a carrier of learning information / messages. Each type of learning media has its characteristics, advantages and disadvantages. That is why it is necessary to have a systematic planning for the use of instructional media.

Applying the Computer Based Instruction method or computer-based learning can be implemented in multimediabased learning on traditional music of Gondang Batak Toba with the use of virtual studio technology

\section{REFERENCES}

[1] A. Munib, Introduction to Education. Semarang: UPT MKK UNNES, 2004.

[2] Hujair AH. Sanaky, Learning Media. Yogyakarta: Safiria Insania Press, 2009.

[3] N. Sudjana and A. Rivai, Teaching Media. Bandung: Sinar Baru, 1991.

[4] O. Hamalik, Educational Media, Prints VI. Bandung: PT Citra Aditya Bakti, 2003. 